\title{
Purification and partial genome characterization of the bacterial endosymbiont Blattabacterium cuenoti from the fat bodies of cockroaches
}

\author{
Gaku Tokuda*1,2, Nathan Lo ${ }^{3}$, Aya Takase ${ }^{1}$, Akinori Yamada4, \\ Yoshinobu Hayashi ${ }^{2}$ and Hirofumi Watanabe*2
}

Address: ${ }^{1}$ Center of Molecular Biosciences (COMB), University of the Ryukyus, Nishihara, Okinawa 903-0213, Japan, ${ }^{2}$ National Institute of Agrobiological Science, Tsukuba, Ibaraki 305-8634, Japan, ${ }^{3}$ Australian Museum, Sydney, NSW 2010, Australia and ${ }^{4}$ Laboratory of Forest Ecology, Graduate School of Agriculture, Kyoto University, Kyoto 606-8502, Japan

Email: Gaku Tokuda* - tokuda@comb.u-ryukyu.ac.jp; Nathan Lo - nathan.lo@austmus.gov.au; Aya Takase - ayatakase@hotmail.co.jp; Akinori Yamada - ayamada@kais.kyoto-u.ac.jp; Yoshinobu Hayashi - hayasiy@mail.goo.ne.jp; Hirofumi Watanabe* - hinabe@affrc.go.jp

* Corresponding authors

Published: 25 November 2008

BMC Research Notes 2008, I:II8 doi:10.1 186/1756-0500-I-II8
Received: 14 October 2008

Accepted: 25 November 2008

This article is available from: http://www.biomedcentral.com//756-0500/I/I I8

(C) 2008 Tokuda et al; licensee BioMed Central Ltd.

This is an Open Access article distributed under the terms of the Creative Commons Attribution License (http://creativecommons.org/licenses/by/2.0), which permits unrestricted use, distribution, and reproduction in any medium, provided the original work is properly cited.

\begin{abstract}
Background: Symbiotic relationships between intracellular bacteria and eukaryotes are widespread in nature. Genome sequencing of the bacterial partner has provided a number of key insights into the basis of these symbioses. A challenging aspect of sequencing symbiont genomes is separating the bacteria from the host tissues. In the present study, we describe a simple method of endosymbiont purification from complex environment, using Blattabacterium cuenoti inhabiting in cockroaches as a model system.

Findings: $B$. cuenoti cells were successfully purified from the fat bodies of the cockroach Panesthia angustipennis by a combination of slow- and fast-speed centrifugal fractionations, nylon-membrane filtration, and centrifugation with Percoll solutions. We performed pulse-field electrophoresis, diagnostic PCR and random sequencing of the shoutgun library. These experiments confirmed minimal contamination of host and mitochondrial DNA. The genome size and the $\mathrm{G}+\mathrm{C}$ content of B. cuenoti were inferred to be $650 \mathrm{~kb}$ and $32.1 \pm 7.6 \%$, respectively.

Conclusion: The present study showed successful purification and characterization of the genome of $B$. cuenoti. Our methodology should be applicable for future symbiont genome sequencing projects. An advantage of the present purification method is that each step is easily performed with ordinary microtubes and a microcentrifuge, and without DNase treatment.
\end{abstract}

\section{Background}

Many eukaryotes have developed symbiotic relationships with bacterial endocytosymbionts $[1,2]$. These symbioses typically involve provision of nutrients by the bacterial partner to its host, and/or manipulation by the bacterial partner of the hosts' reproductive system [3]. Prior to the recent genomic revolution, details of their metabolism and physiology of many of these bacteria remained unknown, in part due to the difficulty of culturing these bacteria. Genome analyses have provided a wealth of information that will be crucial for elucidating the biology of these endosymbionts. The focus has been on symbionts 
in the phylum proteobacteria [4-13], although a few representatives of the other phyla have recently been sequenced $[14,15]$.

A challenging step in sequencing symbiont genomes is purification of the bacterial cells. In some cases, bacterial DNA that was directly extracted from accumulated bacteriocytes was pure enough for sequencing analyses [5,9]. However, in other cases, it was necessary to remove contaminated DNA derived from host nuclei and/or mitochondria. For example, purification of Blochmannia and Wolbachia required the precise adjustment of treatment conditions of DNase I in order to remove DNA of contaminated organelles $[6,16]$; failure of this treatment caused complete digestion of the bacterial genome [16]. This problem was avoided during purification of Buchnera from aphids by use of Percoll-gradient centrifugation to separate the bacterial cells from other organelles or cellular debris [17]. An elegant method was applied to purify TG-1 bacteria from termite flagellates, where a single protozoan cell was manipulated and the posterior part of the protist cell was manually ruptured to collect the specific bacteria [15]. Additional examples of successful endosymbiont isolation from complex environments may facilitate the study of other bacterial symbioses.

Almost all cockroaches harbour the bacterial endocytosymbiont Blattabacterium cuenoti (phylum Bacteriodetes, class Flavobacteria) in mycetocytes of their fat bodies. Molecular phylogenetic studies show this bacterium is closely related to other Flavobacterial endosymbionts of insects, in particular Sulcia muelleri from auchenorrhynchan insects and male-kiling symbionts from ladybird beetles [18]. The Blattabacterium/cockroach symbiosis was first discovered in the late $19^{\text {th }}$ century [19]. These bacteria have been co-evolving with cockroaches for at least 130 million years $[20,21]$. It has been proposed that the symbiosis is mediated by juvenile hormone secreted from corpora allata [22]. On the basis of extensive biochemical, radiochemical, and antibiotic studies using normal and aposymbiotic cockroaches, the relationship has been shown to be one of obligate mutualism. The bacteria contribute to the nitrogen metabolism of their hosts by mobilizing the uric acid stored in the fat bodies when cockroaches feed on nitrogen-poor diets $[23,24]$. The uricolysis is thought to be mediated by xanthine dehydrogenase rather than uricase [23], although further details for this process have yet to be provided. In addition, the bacteria have been proposed to provide some essential amino acids to cockroaches [25] and to be involved in sulphate assimilation into sulphur amino acids [26]. These studies were conducted based on comparisons between normal and aposymbiotic insects, however, effects of the antimicrobial treatments on the intestinal bacterial diversity were not well assessed. Overall, the details of the interaction between the two partners have not yet been clarified.

Genomic or proteomic analyses are likely to greatly enhance our understanding of $B$. cuenoti biology. Purification of $B$. cuenoti cells is the first step in this process. Purification of $B$. cuenoti is challenging for the following reasons. First, the bacterial endosymbionts co-exist with organelles and nuclei that have to be eliminated. Second, in the fat body tissues, the mycetocyte is always surrounded by urocytes and trophocytes [27], which contain a large amount of urates, lipids, and other intracellular extra substances as well as usual organelles and nuclei. In the present paper, we describe the first successful purification of the genomic DNA of the flavobacterial endosymbiont in cockroaches.

\section{Methods \\ Host insects}

Panesthia angustipennis were collected at Mt. Tsukuba in Ibaraki prefecture, Japan. The cockroaches were reared with wood chips and sliced pieces of fresh carrot at room temperature.

\section{Purification of B. cuenoti from cockroaches}

All procedures were performed at $4{ }^{\circ} \mathrm{C}$ unless otherwise indicated. Two adult female individuals (6.5 g in total) were dissected to remove the fat bodies. The collected fat bodies were homogenized in $6 \mathrm{ml}$ of a solution with the following components: $41.2 \mathrm{mM}$ sodium chloride, 10.2 $\mathrm{mM}$ sodium hydrogen carbonate, $5.7 \mathrm{mM}$ trisodium citrate and $14.5 \mathrm{mM}$ potassium dihydrogenphosphate, and fixed in $2.5 \%$ formaldehyde for $2 \mathrm{~h}$. The sample was centrifuged at $1700 \times \mathrm{g}$ for $40 \mathrm{~min}$ and the pellet was suspended in $2 \mathrm{ml}$ of the same solution. The suspension was centrifuged at $300 \times g$ for $2 \mathrm{~min}$ to remove the precipitates. The supernatant was centrifuged at $5000 \times g$ for $20 \mathrm{~min}$ and the pellet was suspended in $1.5 \mathrm{ml}$ of the same solution. This centrifugal step was repeated three times. The final suspension was filtered through nylon membranes of pore sizes $90 \mu \mathrm{m}$ and $25 \mu \mathrm{m}$ to remove the remaining large debris. The filtrate was centrifuged at $5000 \times g$ for 20 min and the pellet was suspended in $500 \mu \mathrm{l}$ of the initial solution. To separate the bacterial cells from mitochondria and the host nuclei, the suspension was overlaid on 5 $\mathrm{ml}$ of 30\% Percoll solution (containing 5.5\% PEG6000, $1.1 \%$ Ficoll, and $278 \mathrm{mM}$ sucrose), which had been overlaid on $5 \mathrm{ml}$ of $70 \%$ Percoll solution (containing 5\% PEG6000, 1\% Ficoll, and $250 \mathrm{mM}$ sucrose) in advance. The sample was centrifuged at $12,000 \times g$ for $20 \mathrm{~min}$, and bacterial cells present between the 30\% and 70\% Percoll phases were collected. Alternatively, $50 \mu \mathrm{l}$ of the suspension was overlaid on $500 \mu \mathrm{l}$ of the $30 \%$ Percoll solution and centrifuged at $12,000 \times g$ for $20 \mathrm{~min}$. Pellet was sus- 
pended in $50 \mu \mathrm{l}$ of $0.2 \mu \mathrm{m}$ filter-sterilized distilled water and overlaid on $500 \mu \mathrm{l}$ of the $70 \%$ Percoll solution. After centrifugation at $12,000 \times \mathrm{g}$ for $20 \mathrm{~min}$, bacterial cells remained on the $70 \%$ Percoll solution were collected. The collected bacterial cells were washed with five volumes of the initial solution or filter-sterilized distilled water and centrifuged to form a bacterial pellet. An aliquot of the bacterial cells was stained with DAPI (4',6'-diamidino-2phenylindole) and observed with an epifluorescence microscope.

\section{Pulse-field gel electrophoresis (PFGE)}

Agarose embedded DNA (plug) was prepared using a CHEF bacterial genomic DNA plug kit (Bio-Rad, Hercules, CA, USA). The plug was extensively washed with TE and treated with $200 \mathrm{U}$ of the homing enzyme I-Ceu I (New England Biolabs, Bevely, MA, USA) in $500 \mu$ l of $1 \times$ digestion buffer $(50 \mathrm{mM}$ potassium acetate, $20 \mathrm{mM}$ Tris-acetate, $10 \mathrm{mM}$ magnesium acetate, $1 \mathrm{mM}$ dithiothreitol (DTT), and $100 \mu \mathrm{g} / \mathrm{ml}$ bovine serum albumin, $\mathrm{pH}$ 7.9) to linearize the genomic DNA by cutting the prokaryotic $23 \mathrm{~S}$ rRNA gene. The plug was briefly rinsed with $0.5 \%$ SDS in $0.5 \times$ TBE $(1 \times$ TBE consists of $0.89 \mathrm{M}$ Tris- $\mathrm{HCl}, 0.89 \mathrm{M}$ boric acid, and $20 \mathrm{mM}$ EDTA, $\mathrm{pH}$ 8.3) and applied to PFGE.

The plug was embedded in a contour-clamped homogeneous electric field (CHEF) gel (1\%) and the bacterial DNA was run using a CHEF-DRII system (Bio-Rad) at 10$15^{\circ} \mathrm{C}$. The electrophoresis was carried out with a pulse switching time of every $60 \mathrm{~s}$ over $15 \mathrm{~h}$, then every $90 \mathrm{~s}$ over $9 \mathrm{~h}$ in $0.5 \times \mathrm{TBE}$ (as running buffer) at $200 \mathrm{~V}(6 \mathrm{~V} / \mathrm{cm})$. To check the presence or absence of DNA fragments less than $250 \mathrm{~kb}$ in length, electrophoresis was performed with gradual increase of the pulse switching time from $30 \mathrm{~s}$ to $90 \mathrm{~s}$ over $24 \mathrm{~h}$ at $150 \mathrm{~V}$. The presence or absence of DNA fragments less than $10 \mathrm{~kb}$ was checked by conventional electrophoresis with a $1 \%$ agarose gel. The gels were stained with ethidium bromide and observed on a UV trans-illuminator.

To confirm the genome size, the plug was treated with 200 $\mathrm{U}$ of the restriction enzyme Ksp I (= Sac II or Sst II) (Roche, Penzberg, Germany) in $500 \mu \mathrm{l}$ of $1 \times$ digestion buffer (10 $\mathrm{mM}$ Tris- $\mathrm{HCl}, 10 \mathrm{mM}$ magnesium chloride, and $1 \mathrm{mM}$ dithioerythritol, pH 7.5). Pulse-Field electrophoresis was performed at $6 \mathrm{~V} / \mathrm{cm}$ using ramped pulse times from 5 to $20 \mathrm{~s}$ for $18 \mathrm{~h}$, followed by a pulse switching time of every $60 \mathrm{~s}$ over $15 \mathrm{~h}$, then every $90 \mathrm{~s}$ over $6 \mathrm{~h}$ in $0.5 \times$ TBE.

\section{DNA purification and diagnostic PCR}

To check if the DNA band actually originated from the purified B. cuenoti, the band was excised from the gel and washed with $1 \times \beta$-Agarase I Reaction Buffer $(10 \mathrm{mM}$ Bis Tris-HCl, 1 mM EDTA, pH 6.5) (New England Biolabs).
The agarose block containing the DNA band was completely melted at $90^{\circ} \mathrm{C}$ and was cooled to $50^{\circ} \mathrm{C}$. Then, $\beta$ Agarase I (New England Biolabs) was added to be $20 \mathrm{U} /$ $\mathrm{ml}$ and the sample was incubated at $45^{\circ} \mathrm{C}$ for $1 \mathrm{~h}$. The bacterial genomic DNA was extracted using a conventional phenol/chloroform method [28]. The genomic DNA collected with ethanol precipitation was dissolved in $50 \mu \mathrm{l}$ of sterilized distilled water, which was used as PCR template.

Diagnostic PCR was performed using forward (5'-GAT GGC GAC CGG CGT ACG GGT GCG-3', positions corresponding to 45-68 of Genbank $\underline{\mathrm{AB} 231604}$ ) and reverse (5'-TAC ACC ACA CAT TCC AGC TAC TCC-3', positions corresponding to 641-618 of AB231604) primers specific for 16S rDNA of B. cuenoti, A-tLEU and B-tLYS [29] specific for mitochondrial cytochrome oxidase II, and newly designed forward (5'-AAA TTA CCC ACT CCC GGC AC-3', positions corresponding to 3-22 of Genbank $\underline{A B 036190}$ ) and reverse (5'-TGG TGC CCT TCC GTC AAT TC-3', positions corresponding to 829-810 of AB036190) primers specific for $18 \mathrm{~S}$ rDNA of $P$. angustipennis, respectively. The temperature regimen for 30 cycles was $94^{\circ} \mathrm{C}$ for $30 \mathrm{~s}$, $52^{\circ} \mathrm{C}$ for $30 \mathrm{~s}$, and $72^{\circ} \mathrm{C}$ for $1 \mathrm{~min}$. The amplified fragment size was confirmed by $1 \%$ agarose gel electrophoresis.

\section{Amplification of the whole genome and construction of shotgun library}

To obtain the sufficient amount of DNA, the total genomic DNA extracted from the CHEF gel was amplified with a proofreading phi29 DNA polymerase using a GenomiPhi DNA amplification kit (GE Healthcare, Buckinghamshire, UK). The shotgun library ( $2 \mathrm{~kb}$ ) was constructed with a modification of the previous method [5]. Briefly, the amplified DNA was hydrodynamically cut ( $\sim 2$ $\mathrm{kb}$ ) with the hydroshear DNA shearer (Digilab Genomic Solutions, Ann Arbor, MI). The fragmented DNA was treated with DNA polymerase I and blunt-ended with T4 DNA polymerase. After conventional agarose gel electrophoresis, DNA fragments were excised from the gel at the area of $2 \mathrm{~kb}$ in size and purified. The obtained DNA fragments were ligated at the Hinc II site of phospholylated pUC118 plasmid vector and transformed into Escherichia coli DH10B. 96 clones were randomly selected and onepass sequences were determined using an ABI 3700 sequencer.

\section{Results and discussion Development of the purification method of B. cuenoti cells}

A challenge in genomic analyses of bacterial endosymbionts is purification of bacterial cells. Thus, we aimed to develop a simple purification method for endocytosymbionts from a complex environment. Unlike the case for some insects, it is not possible to manually isolate bacte- 
riocytes from the fat bodies of cockroaches. Thus, we employed four purification steps to obtain the pure B. cuenoti. The first step was to collect only fat bodies from the cockroaches by dissection. The structure of $B$. cuenoti cells throughout the purification steps was aided by immediate fixation of the fat body homogenate with paraformaldehyde. The second step was a combination of fast- and slow-speed centrifugal fractionations to separate $B$. cuenot $i$ from larger and smaller cellular or cytosolic debris and lipids. The third step was filtration of the centrifuged homogenate with nylon membranes to eliminate remaining larger debris from the sample. However, these steps did not separate the bacterial cells from mitochondria and host nuclei. Therefore, to purify the bacterial cells without DNase treatment, we initially tried Percoll gradient centrifugation based on the purification method of Buchnera [17] as well as an autogradient formation with Percoll using an ultracentrifuge. However, the bacterial band was not formed in the gradient solutions. Instead of the gradient centrifugation, we employed a two-layered Percoll centrifugation, where the concentrations of the ingredients in the Percoll solutions were precisely adjusted during preliminary experiments. This method eventually resulted in a white band between the upper (30\%) and bottom (70\%) Percoll layers (Fig. 1). Light microscopic observation revealed that the purified sample consisted of short bacterial rods with a slight contamination of small particles (Fig. 2A). However, DAPI signals were only detected from the short rods, thus contaminations of neither mitochondria nor nuclei were observed (Fig. 2B). The short rods ranged in length from approximately 2 to $5 \mu \mathrm{m}$ and often formed binary fission pairs (Fig. 2B). These morphologies are consistent with those of the previously reported Blattabactterium [30,31], suggesting the successful purification of the endosymbiont. We also found that the two-layered Percoll centrifugation was not mandatory. Centrifugation with $30 \%$ Percoll solution in a microtube followed by centrifugation with the $70 \%$ solution produced the same result as Fig. 2. Stepwise changes in the concentration of the Percoll solutions with microtubes may enable to this method to be applied to other endosymbionts living in similarly complex host environments.

\section{Genome size estimation and purity confirmation}

To achieve complete purification of the bacterial DNA, we performed pulse-field gel electrophoresis (PFGE) using plugs prepared from the purified bacterial cells. If the genome is circular, the DNA does not migrate smoothly in CHEF gels during PFGE [16]. In the present study, linearization of the bacterial chromosome with an enzymatic cleavage was necessary prior to electrophoresis. Although we initially tried to digest the DNA with the restriction enzyme Not I (that recognizes an 8-bp motif rich in G and C), no bands were observed. Thus, we treated the bacterial DNA with the homing endonuclease I-Ceu I, that cleaves

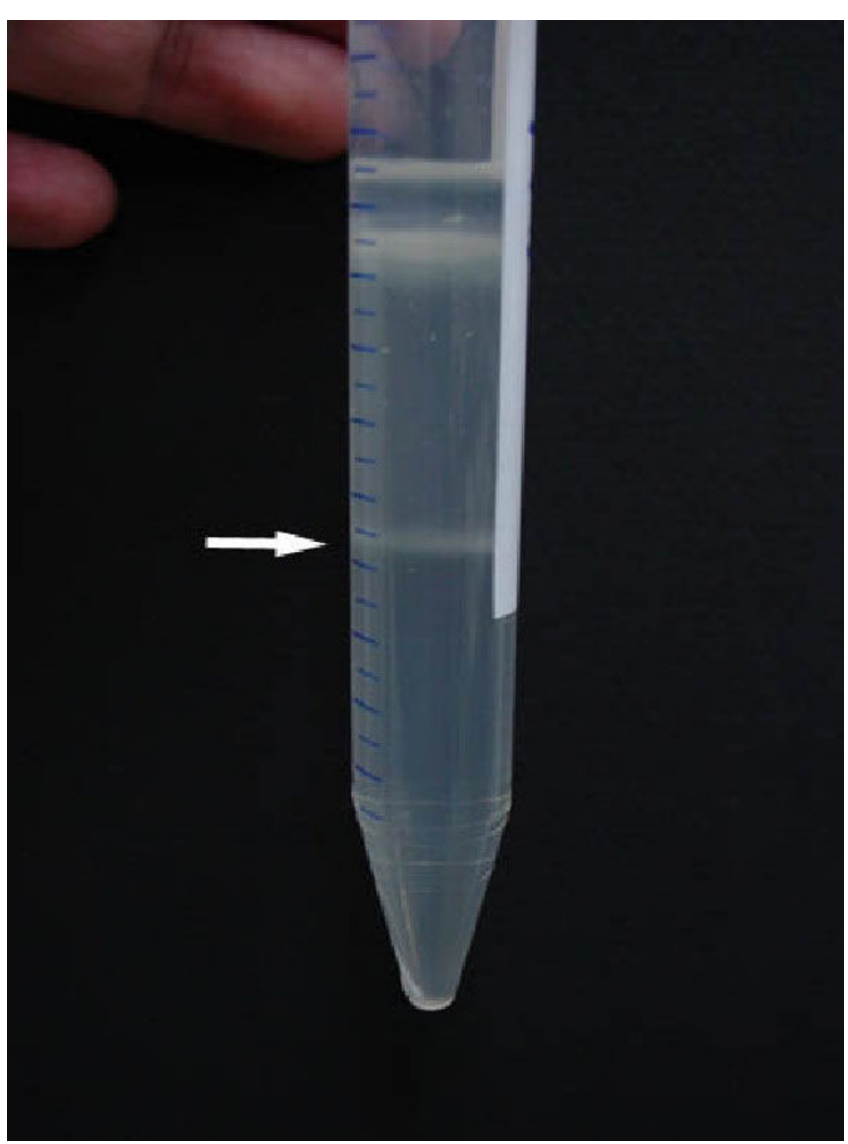

Figure I

Purification of B. cuenoi cells by two-layered Percoll centrifugation. $B$. cuenoti cells (arrow) between two layers of the Percoll solutions after centrifugation at $12,000 \times \mathrm{g}$ for $20 \mathrm{~min}$.

many prokaryotic $23 \mathrm{~S}$ rRNA genes at only one specific site [32]. Fig. 3 shows the electrophoretogram of the genomic DNA from B. cuenoti. The electrophoresis resulted in only one band; the absence of other bands was confirmed under other PFGE conditions and conventional submarine electrophoresis. The results suggest that $B$. cuenot $i$ possesses only one copy of the ribosomal RNA gene complement (i.e. 5S, 16S, and 23S rDNAs) on a circular genome, as is the case of the majority of other bacterial endosymbionts (i.e. Buchnera spp., Blochmannia spp., and Carsonella ruddii). The size of the bacterial genomic DNA was estimated to be $650 \mathrm{~kb}$ by comparing its mobility with chromosomal fragments of Saccharomyces cerevisiae on PFGE (Fig. 3). This result was further confirmed with the other restriction enzymes, Ksp I, which produced two fragments (see Additional file 1). No evidence for extrachromosomal plasmids was found.

To check the origin of the DNA band, PCR was performed using primers specific for the B. cuenoti $16 \mathrm{~S}$ rDNA, cock- 

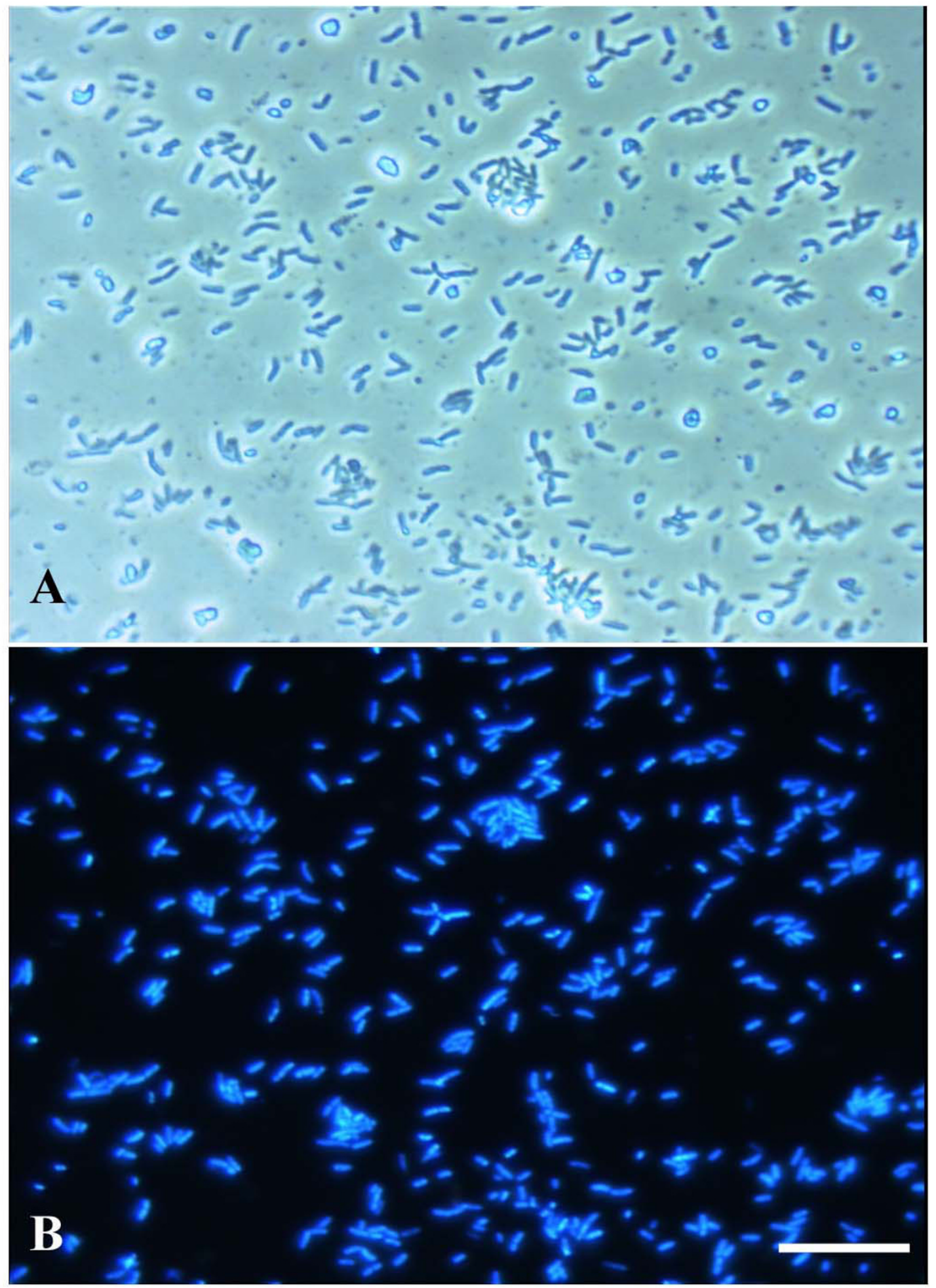

Figure 2

Purified bacterial cells of B. cuenoti. Light micrograph of purified B. cuenoti. B. Fluorescent image of DAPI-stained B. cuenoti, which is the same field as that shown as (a). Bar, $25 \mu \mathrm{m}$. 


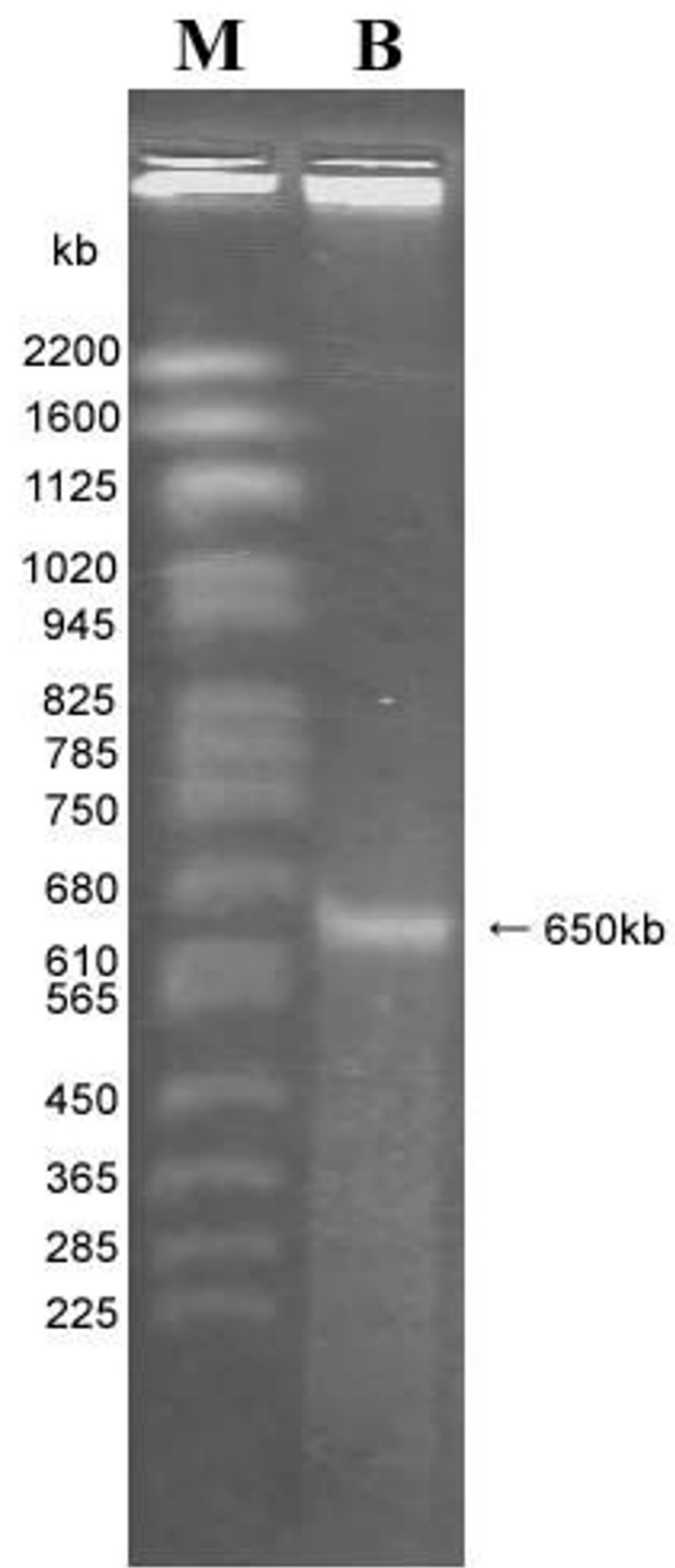

Figure 3

Electrophoretogram of the genomic DNA from $B$. cuenoti in the CHEF gel. M: Marker DNA of S. cerevisiae chromosomes (Bio-Rad). B: Genomic DNA of B. cuenoti. Arrow indicates the DNA band observed. roach $18 \mathrm{~S}$ rDNA, and mitochondrial COII. Contamination of mitochondrial or host nuclear DNA was significantly removed from the sample collected after the Percoll centrifugation and eventually not detected after PFGE (Fig. 4). Since only a trace of amplification of contaminated DNA was detected without the Percoll centrifugation (Fig. 4B), PFGE separation of genomic DNA may be only necessary when very pure DNA is required for further experiments.

So far, intracellular endosymbiont genome sequencing projects have primarily focused on members of the proteobacteria phylum (Table 1). The genomes of these endosymbionts range from $450 \mathrm{~kb}$ to $1.7 \mathrm{Mb}$ (Table 1 ), with the exception of the psyllids bacterial symbiont $(160$ $\mathrm{kb})$ [9], the secondary flavobacterial endosymbiont of sharpshooters (245 kb) [14], and the secondary endosymbiont of tsetse flies (4.2 Mb) [33]. From comparisons with their free-living relatives, it is widely accepted that the intracellular symbionts have lost significant amounts of genomic information since adopting the intracellular lifestyle [3]. Indeed, the secondary endosymbiont of tsetse flies, Sodalis glossinidius, which was recently diverged from a free-living ancestor, shows a large genome size (4.2 Mb) and massive slow erosion at individual loci [33]. Free-living and parasitic relatives in Flavobacteria have genome sizes ranging from 2.7 to $6 \mathrm{Mb}$ (Table 1), compared with $650 \mathrm{~kb}$ for B. cuenoti. Thus B. cuenoti is likely to have lost a significant number of genes since its ancestors first entered into a symbiotic relationship with insects. The present study is the second demonstration of a Bacteroidetes symbiont with a reduced genome, the first being Sulcia muelleri $(245 \mathrm{~kb})$ [14]. While B. cuenoti is a primary symbiont, $S$. muelleri co-inhabits sharpshooter cells with the primary endosymbiont Baumannia cicadellinicola [14]. Very recently, the small genome $(1.1 \mathrm{Mb})$ of a bacterial endosymbiont (phylum TG-1) of termite flagellates has been determined [15]. In addition, similar genome reduction has also been reported from commensal and parasitic microbes such as those belonging to chlamydiae, rickettsiae, and mollicutes $[34,35]$. These findings strongly suggest evolutionary plasticity of bacterial genomes in response to their lifestyles and endosymbiotic genome reduction as a phenomenon that occurs across different bacterial phyla.

In order to confirm that the genomic DNA was pure enough for further applications, we constructed the shotgun library and randomly selected 96 clones were onepass sequenced (see Additional file 2). Except for 6 clones that possessed vector-derived contaminants, only one clone showed apparent contamination of the host genomic DNA, while no mitochondrial DNA was detected. The average $\mathrm{G}+\mathrm{C}$ content of the DNA fragments (excluding the host and contaminated vector DNA frag- 


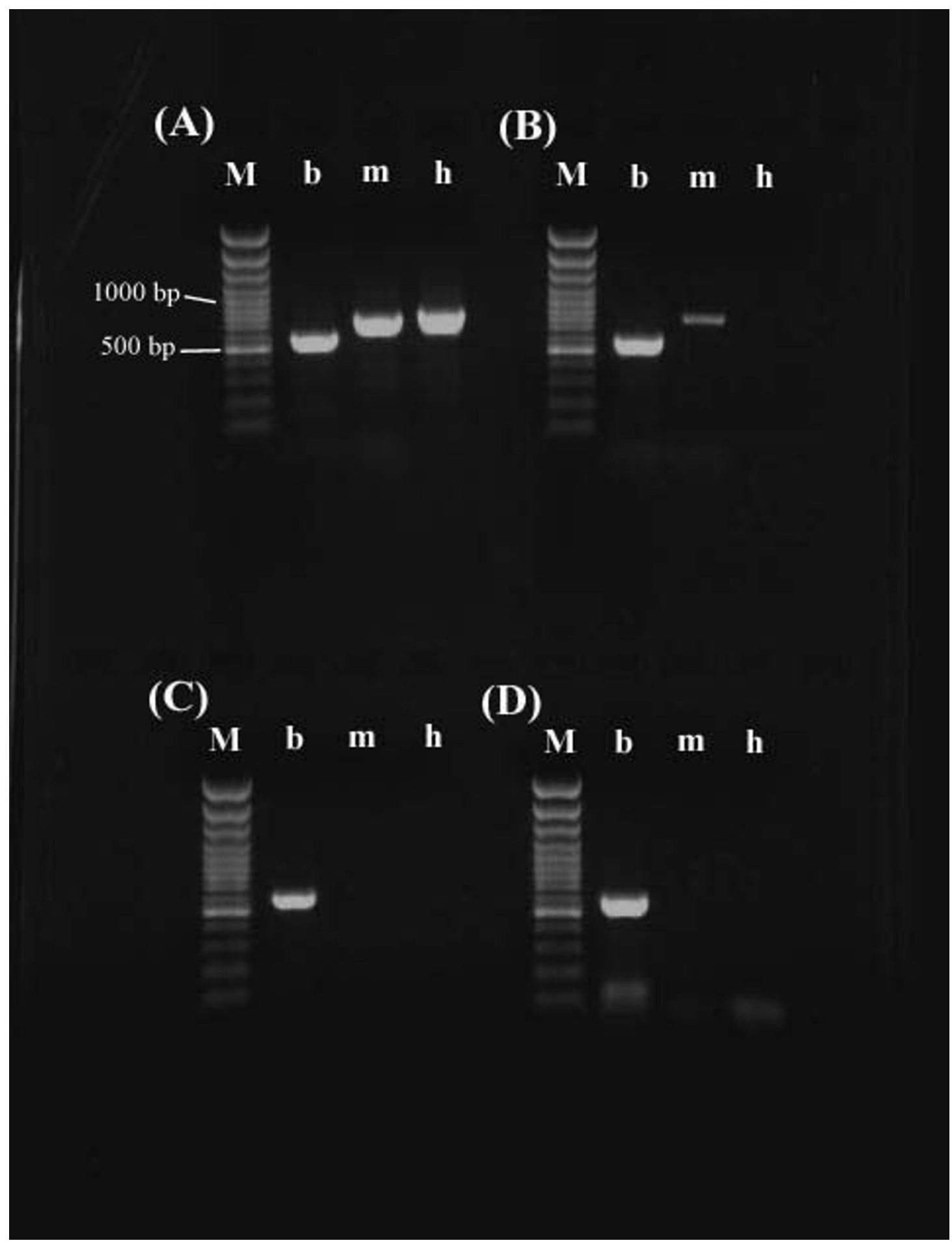

\section{Figure 4}

Diagnostic PCR using DNA extracted during purification of the bacterial endosymbiont. A. When PCR was performed using a template prepared from the fat bodies, DNA fragments of $B$. cuenoti (b), mitochondria (m) and host Panesthia nuclei $(\mathrm{h})$ were observed. $B$. Although the host DNA was disappeared after the Percoll centrifugation, only a trace of contamination of mitochondrial DNA was amplified. C. When the B. cuenoti DNA was digested with I-Ceu I separated using PFGE, no contaminations of mitochondrial and host's DNAs were detected. D. As PCR cycles were increased to be 35 cycles, no contaminations were detectable. M: 100-bp ladder. 
Table I: Comparison of genome sizes among free-living, pathogenic and endosymbiotic bacteria

\begin{tabular}{ll}
\hline Bacterial species (host or origin) & Genome size (Reference) \\
\hline Bacteriodetes, class Flavobacteria & \\
Flavobacterium johnsoniae (free-living) & $\sim 6 \mathrm{Mb}$ (Genbank AAPM00000000) \\
Leeuwenhoekiella blandensis (free-living) & $4.24 \mathrm{Mb}[36]$ \\
Polaribacter irgensii (free-living) & $2.74 \mathrm{Mb}[36]$ \\
F. Psychrophilum (a fish pathogen) & $2.86 \mathrm{Mb}[37]$ \\
Sulcia muelleri (sharpshooters) & $245 \mathrm{~kb}[\mathrm{I4}]$ \\
Blattabacterium cuenoti (cockroaches) & $650 \mathrm{~kb}$ (this study) \\
Proteobacteria Endosymbionts & \\
Baumannia cicadellinicola (sharpshooters) & \\
Blochmannia floridanus (carpenter ants) & $686 \mathrm{~kb}[\mathrm{II}]$ \\
Buchnera spp. (pea arphids) & $705 \mathrm{~kb}[6]$ \\
Carsonella ruddii (psyllids) & $416-640 \mathrm{~kb}[4,10]$ \\
Sodalis glossinidius (tsetse flies) & $160 \mathrm{~kb}[9]$ \\
Wigglesworthia glossinidia (tsetse flies) & $4.17 \mathrm{Mb}[33]$ \\
Wolbachia spp. (insects and nematodes) & $698 \mathrm{~kb}[5]$ \\
Caryptogena symbiont (deep-sea clams) & $0.95-1.66 \mathrm{Mb}[7,8,16]$ \\
Riftia magnifica (deep-sea clams) & $1.02 \mathrm{Mb}[\mathrm{I}]$ \\
Termite Group I Endosymbiont & $1.16 \mathrm{Mb}[\mathrm{I3}]$ \\
Trichonympha symbiont (termite flagellates) & \\
\hline
\end{tabular}

ments) was $32.1 \pm 7.6 \%$ (see Additional file 2), which is consistent with many other reduced genomes of endosymbionts showing relatively low $\mathrm{G}+\mathrm{C}$ content ranging from 16.6 to $35 \%[12,14]$. The genomes of free-living Bacteroidetes species typically have more than $40 \% \mathrm{G}+\mathrm{C}$ content [14].

The present method will facilitate genome sequence analysis of $B$. cuenoti, thereby providing important information on which genes have been retained by the symbiont to contribute to the host's metabolism. The ability to break down uric acid, one of the most intriguing functions predicted in B. cuenoti, is rare among members of Flavobacterium genus, which represent the closest free-living relatives. It will thus be interesting to see the phylogenetic affinity of uricolytic genes in B. cuenoti, if they are present in the genome.

\section{Competing interests}

The authors declare that they have no competing interests.

\section{Authors' contributions}

GT, NL, AY, and HW designed the research project. GT, AT, and HW collected the insects. GT, AT and YH performed the purification and PFGE experiments. GT annotated the sequences of the shotgun library. GT and NL wrote the paper. All authors approved and read the final manuscript.

\section{Additional material}

\section{Additional file 1}

Fig. S1 Electrophoretogram of the genomic DNA from B. cuenoti in the CHEF gel. The genomic DNA was cut with Ksp I. The sum of the restricted fragment sizes was consistent with the result shown as Fig. 3. M1: Marker DNA of S. cerevisiae chromosomes. M2: MidRange PFG Marker I (New England Biolabs). B: Genomic DNA of B. cuenoti. Click here for file

[http://www.biomedcentral.com/content/supplementary/17560500-1-118-S1.jpeg]

\section{Additional file 2}

Table S1 Sequencing analysis of the shotgun library clones. Click here for file

[http://www.biomedcentral.com/content/supplementary/17560500-1-118-S2.xls]

\section{Acknowledgements}

We thank G. Arakawa at University of the Ryukyus for his valuable help to collect the insects. This work was supported by the 2 Ist $^{\text {st }} \mathrm{COE}$ program of University of the Ryukyus and by Grant-in-Aids of Scientific Research (KAKENHI No 18380045 and 17405025). NL was supported by an Australian Research Council Postdoctoral Fellowship.

\section{References}

I. Buchner P: Endosymbiosis of animals with plant microorganisms. New York: Interscience; 1965.

2. Wernegreen J]: Genome evolution in bacterial endosymbionts of insects. Nat Rev Genet 2002, 3:850-861.

3. Dale C, Moran NA: Molecular interactions between bacterial symbionts and their hosts. Cell 2006, I 26:453-465. 
4. Shigenobu S, Watanabe H, Hattori M, Sakaki Y, Ishikawa H: Genome sequence of the endocellular bacterial symbiont of aphids Buchnera sp. APS. Nature 2000, 407(6800):8I-86.

5. Akman L, Yamashita A, Watanabe H, Oshima K, Shiba T, Hattori M, Aksoy S: Genome sequence of the endocellular obligate symbiont of tsetse flies, Wigglesworthia glossinidia. Nat Genet 2002, 32:402-407.

6. Gil R, Silva FJ, Zients E, Delmotte F, González-Candelas F, Latorre A, Rausell C, Kamerbeek J, Gadau J, Hölldobler B, van Ham RCHJ, Gross $R$, Moya $A$ : The genome sequence of Blochmannia floridanus: comparative analysis of reduced genomes. Proc Natl Acad Sci USA 2003, 100:9388-9393.

7. Wu M, Sun LV, Vamathevan J, Riegler M, Deboy R, Brownlie JC, McGraw EA, Martin W, Esser C, Ahmadinejad N, Wiegand C, Madupu R, Beanan MJ, Brinkac LM, Daugherty SC, Durkin AS, Kolonay JF, Nelson WC, Mohamoud Y, Lee P, Berry K, Young MB, Utterback T, Weidman J, Nierman WC, Paulsen IT, Nelson KE, Tettelin H, O'Neill SL, Eisen JA: Phylogenomics of the reproductive parasite Wolbachia pipientis wMel: a streamlined genome overrun by mobile genetic elements. PLoS Biol 2004, 2(3):e69.

8. Foster J, Ganatra M, Kamal I, Ware J, Makarova K, Ivanova N, Bhattacharyya A, Kapatral V, Kumar S, Posfai J, Vincze T, Ingram J, Moran L, Lapidus A, Omelchenko M, Kyrpides N, Ghedin E, Wang S, Goltsman E, Joukov V, Ostrovskaya O, Tsukerman K, Mazur M, Comb D, Koonin E, Slatko B: The Wolbachia Genome of Brugia malayi: endosymbiont evolution within a human pathogenic nematode. PLOS Biol 2005, 3:el2I.

9. Nakabachi A, Yamashita A, Yoh H, Ishikawa H, Dunbar HE, Moran NA, Hattori M: The 160-kilobase genome of the bacterial endosymbiont Carsonella. Science 2006, 3 14:267.

10. Pérez-Brocal V, Gil R, Ramos R, Lamelas A, Postigo M, Michelena JM, Silva FJ, Moya $A$, Latorre $A$ : A small microbial genome: the end of a long symbiotic relationship? Science 2006, 3 I 4:3 I2-3। 3 .

II. Wu D, Daugherty SC, Van Aken SE, Pai GH, Watkins KL, Khouri H, Tallon LJ, Zaborsky JM, Dunbar HE, Tran PL, Moran NA, Eisen JA: Metabolic complementarity and genomics of the dual bacterial symbiosis of sharpshooters. PLoS Biol 2006, 4:el 88.

12. Kuwahara H, Yoshida T, Takaki Y, Shimamura S, Nishi S, Harada M, Matsuyama K, Takishita K, Kawato M, Uematsu K, Fujiwara Y, Sato T, Kato C, Kitagawa M, Kato I, Maruyama T: Reduced genome of the thioautotrophic intracellular symbiont in a deep-sea clam, Calyptogena okutanii. Curr Biol 2007, 17:88I-886.

13. Newton ILG, Woyke T, Auchtung TA, Dilly GF, Dutton RJ, Fisher MC, Fontanez KM, Lau E, Stewart FJ, Richardson PM, Barry KW Saunders E, Detter JC, Wu D, Eisen JA, Cavanaugh CM: The Calyptogena magnifica chemoautotrophic symbiont genome. Science 2007, 315:998-1000.

14. McCutcheon JP, Moran NA: Parallel genomic evolution and metabolic interdependence in an ancient symbiosis. Proc Natl Acad Sci USA 2007, 104(49): $19392-19397$.

15. Hongoh Y, Sharma VK, Prakash T, Noda S, Taylor TD, Kudo T, Sakaki Y, Toyoda A, Hattori M, Ohkuma M: Complete genome of the uncultured Termite Group I bacteria in a single host protist cell. Proc Natl Acad Sci USA 2008, I 05( I 4):5555-5560.

16. Sun LV, Foster JM, Tzertzinis G, Ono M, Bandi C, Slatko BE, O'Neill $S$ : Determination of Wolbachia genome size by pulse-field gel electrophoresis. J. Bacteriol 200I, I 83:2219-2225.

17. Charles $\mathrm{H}$, Ishikawa $\mathrm{H}$ : Physical and genetic map of the genome of Buchnera, the primary endosymbiont of the pea aphid Acyrthosiphon pisum. J Mol Evol 1999, 48(2):142-150.

18. Gruwell ME, Morse GE, Normark BB: Phylogenetic congruence of armored scale insects (Hemiptera: Diaspididae) and their primary endosymbionts from the phylum Bacteroidetes. Mol Phylogenet Evol 2007, 44:267-280.

19. Blochmann F: Vorkommen bacterienähnliche Köpperchen in den Geweben und Eiern verschiedener Insekten. Biologisches Centralblatt I887, 7:606-608.

20. Bandi C, Sironi M, Damiani G, Magrassi L, Nalepa CA, Laudani U, Sacchi $L$ : The establishment of intracellular symbiosis in an ancestor of cockroaches and termites. Proc R Soc Lond B Biol Sci 1995, 259:293-299.

21. Lo N, Bandi C, Watanabe H, Nalepa C, Beninati T: Evidence for cocladogenesis between diverse dictyopteran lineages and their intracellular endosymbionts. Mol Biol Evol 2003, 20(6):907-913.
22. Philippe C, Latge JP, Prevost MC: In vitro characterization of hormonal action on Periplaneta americana endocytobiotes. Endocytobiosis and Cell Research 1988, 5:95-107 [http://zs.thulb.uni-jena.de/ receive/jportal jparticle 0005996I].

23. Cochran DG: Nitrogen excretion in cockroaches. Ann Rev Entomol 1985, 30:29-49.

24. Wren HN, Cochran DG: Xanthine dehydrogenase activity in the cockroach endosymbiont Blattabacterium cuenoti (Mercier 1906) Hollande and Favre I93 I and in the cockroach fat body. Comp Biochem Physiol 1987, 88B:1023-1026.

25. Henry SM: The significance of microorganisms in the nutrition of insects. Trans N Y Acad Sci 1962, 24:676-683.

26. Henry SM, Block RJ: The sulphur metabolism of insects. IV. The conversion of inorganic sulphate to organic sulphur compounds in cockroaches. Contributions to Boyce Thompson Institute 1960, 20:317-329.

27. Bandi C, Sacchi L: Intracellular symbiosis in termites. In Termites: Evolution, Sociality, Symbioses, Ecology Edited by: Abe T, Bignell DE, Higashi M. Dordrecht, The Netherlands: Kluwer Academic Publisher; 2000:26I-273.

28. Sambrook J, Fritsch EF, Maniatis T: Molecular cloning: a laboratory manual. 2nd edition. Cold Spring Harbor, New York: Cold Spring Harbor Press; 1989.

29. Maekawa K, Lo N, Kitade O, Miura T, Matsumoto T: Molecular phylogeny and geographic distribution of wood-feeding cockroaches in East Asian islands. Mol Phylogenet Evol 1999, 13:360-376.

30. Brooks MA: Comments on the classification of intracellular symbiotes of cockroaches and a description of the species. Invertebr Pathol 1970, 16:249-258.

31. Dasch GA, Weiss E, Chang K: Endosymbionts in insects. In Bergey's Manual of Systematic Bacteriology Volume I. Edited by: Krieg NR, Holt JG. Baltimore, MD: Williams and Wilkins; 1984:8I I-833.

32. Liu SL, Hessel A, Sanderson KE: Genomic mapping with I-Ceu I, an intron-encoded endonuclease specific for genes for ribosomal RNA, in Salmonella spp., Escherichia coli, and other bacteria. Proc Natl Acad Sci USA 1993, 90:6874-6878.

33. Toh H, Weiss BL, Perkin SAH, Yamashita A, Oshima K, Hattori M, Aksoy S: Massive genome erosion and functional adaptations provide insights into the symbiotic lifestyle of Sodalis glossinidius in the tsetse host. Genome Res 2006, 16:149-156.

34. Palmer $\mathrm{GH}$ : The highest priority: what microbial genomes are telling us about immunity. Vet Immunol Immunopathol 2002, 85: $1-8$.

35. Trachtenberg S: Mollicutes. Curr Biol 2005, I 5:R483-R484

36. Pinhassi J, Bowman JP, Nedashkovskaya OI, Lekunberri I, GomezConsarnau L, Pedrós-Alió C: Leeuwenhoekiella blandensis sp. nov., a genome-sequenced marine member of the family Flavobacteriaceae. Int / Syst Evol Microbiol 2006, 56: I489-I 493.

37. Duchaud E, Boussaha M, Loux V, Bernardet J, Michel C, Kerouault B, Mondot S, Nicolas P, Bossy R, Caron C, Bessières P, Gibrat J-F, Claverol S, Dumetz F, Hénaff ML, Benmansour A: Complete genome sequence of the fish pathogen Flavobacterium psychrophilum. Nat Biotechnol 2007, 25(7):763-769.

Publish with Bio Med Central and every scientist can read your work free of charge

"BioMed Central will be the most significant development for disseminating the results of biomedical research in our lifetime. "

Sir Paul Nurse, Cancer Research UK

Your research papers will be:

- available free of charge to the entire biomedical community

- peer reviewed and published immediately upon acceptance

- cited in PubMed and archived on PubMed Central

- yours - you keep the copyright 